\title{
島原牛島眉山に於ける植相變移の考察
}

S. Hatsusima: Eine Beobachtung über die Vegetationssukzession am Berge Bisan.

（昭和六年四月三十日受理）

初島住彥

(1) 緒 言

森林植相變移の研究は、吾々林學者にとりて頗る汗要且興味ある事柄である。然るに椎相

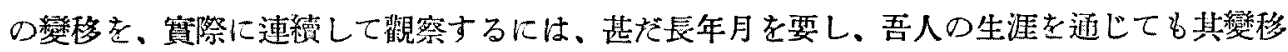
の一小部分しか觀察し得厺い場合が多い。然るに幸ひ著者は、島原牛島雲仙岳の東方に屹立 せる眉山東面山麓の爆發跡地に於て、植相連續變移の研究便なる好材料老見出せるを以

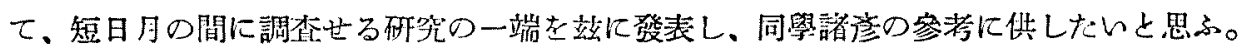

(2) 眉山の地質並飞地形の大要

眉山は雲仙岳の寄生火山をなし、游找 818.7 米吉有する山にして、全部辉石安山岩より成

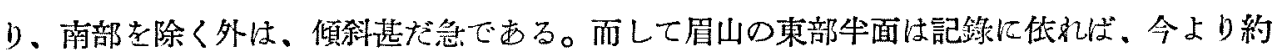

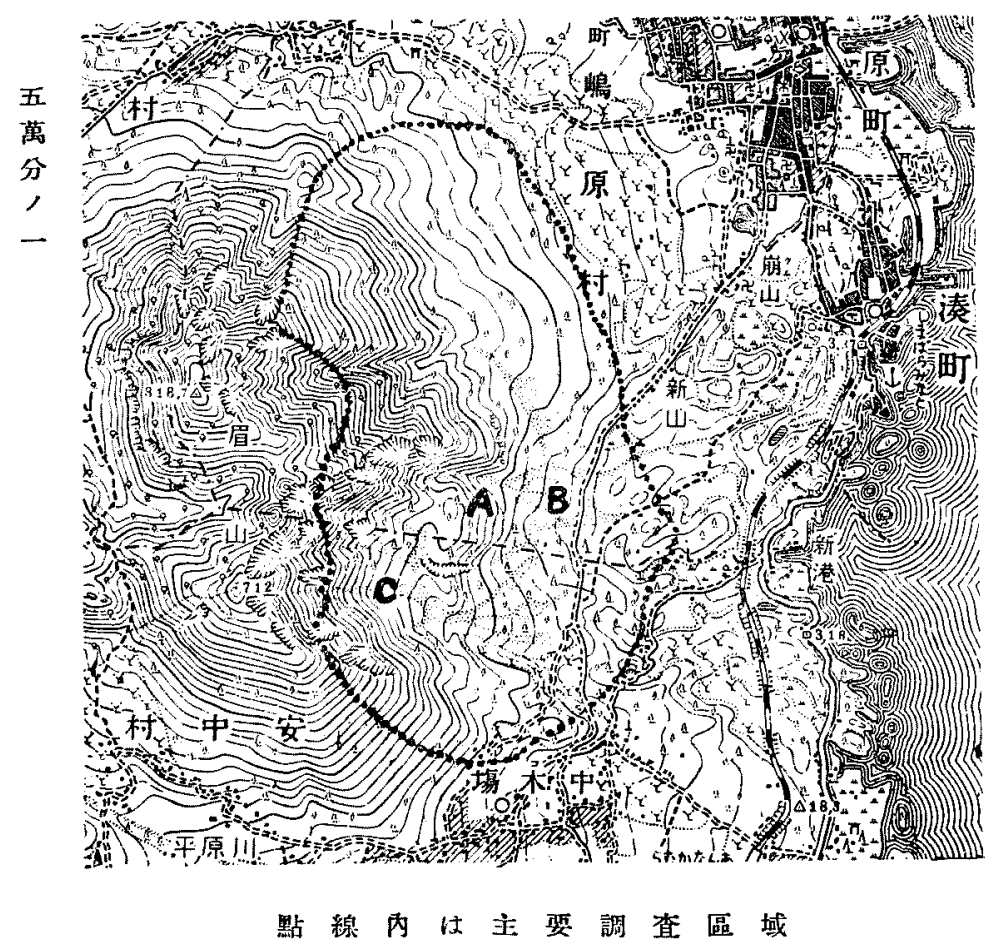




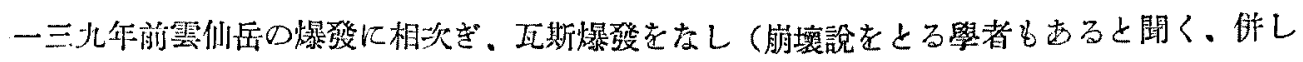
いづれにしても、裸地の發生せることには變りなし) 東部山體の約三分の一は飛散し、士石

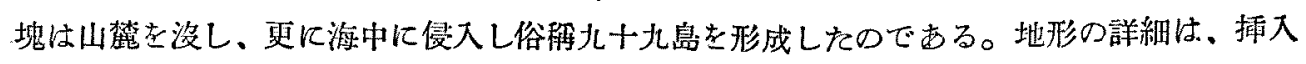
の地圖參照せられたん。

\section{(3) 眉山植物調查一般}

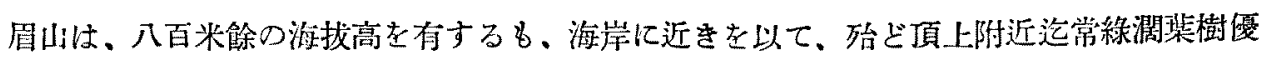
勢占めて居る。

項上附近

ヤシヤブシ、アカシデ、ッリバナ、シラキ、カヘデ、コハウチハカヘデ、ノリウツギ、ウ リノキ、オホコマユミ、シキミ、等の溫帶落葉濶葉樹を主とする。

七百米附近

アカガシを主としそにアクロモジ、ハヒノキ、シキミ、シラカシ、アアハダ、等在混叔。

四百米～六百米附近

ウラジロガシ多く之にサカキ、ヤブニクケイ、イス、コバンモチ、サザンクワ、タブ、ヤ マモガシ、アラカシ等在混蓑る。谷通りには、クマノミッ゙キ、エノキ、ムクノキ、ろヤキ、 アヨガシ、イヌガヤ、キブシ、カへデ、アワブキ等多く、此等の下部にはイメビ八、アヨキ、 イハガネ、コバノハナイカダ、イッ゙センリヨウ等の灌栘し。

\section{二百米〜三百米附近}

クロマツを主とし之にアラカシ、タブ、クス、クロキ、ヒメュッ゙リハ、ヤブニクケイ、ツ バキ、モクコク、等の䁔帶特有の常綵濶㷊樹を下木として混和る。

\section{百 米附 近}

全部クロマツ林(一部間の子松老混永)にして、三十年生百年生のもの最も多く、林內は比

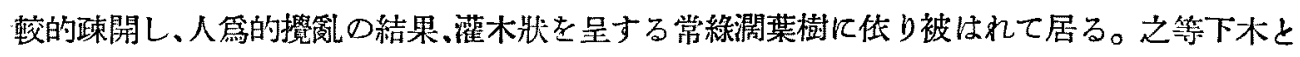
しては、アラカシ、ナナメノキ、クス、クロキ、ナハシログミ、ニシゴリ、ネズミモチ、ヒ メンヅリハ、ポロポロノキ、カンコノキ、ヒサカキ、シャシヤンポ、クチナシ、マルバウッ

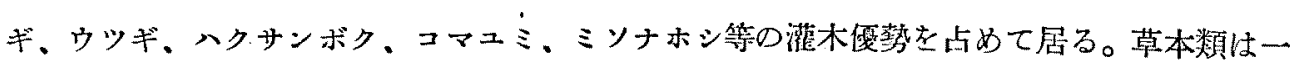

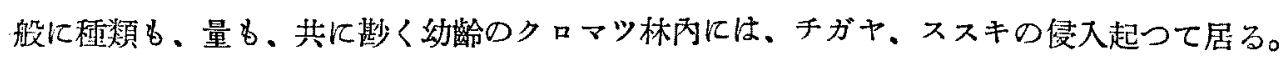

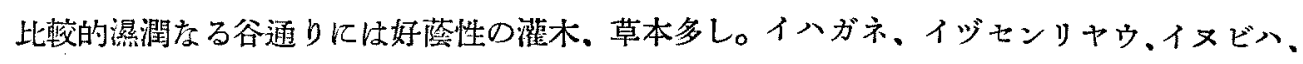
コバノハナイカダ、ガクウツギ、ルリミノキ、ヒンリヤウ、ヤブカウジ、ツルカウシ等の灌 未の外、マツカゼサウ、ミッ゙タマサウ、シニウブンアウ、メマダイコン、シンミッ゙ヒキ、ミ ヅヒキグサ、サッマイナモり、オホハンゲ、ナガバイラクサ等の草本類上共に、才ホキジ ヨ、ホシダ、ミソシダ、キノデ、ホソバカナワラビ、クリハラン、ジュモンジシダ、イハガ 
ネゼンマイ、シケチシダ等の羊萄類繁茂して居る。

次に、眉山の植物總計並に內臎去示寸と羊遥類以上一一九科五八五種にして、之草本。 本本に分けるときは、炏表の如くである。

木 本 172 種草木 413 程

內 譯

\begin{tabular}{|c|c|}
\hline 喬 木 & 64程 \\
\hline 小喬杭 & 39㘪 \\
\hline 灌 & 48 \\
\hline 蒙茎植物 & 2 \\
\hline
\end{tabular}

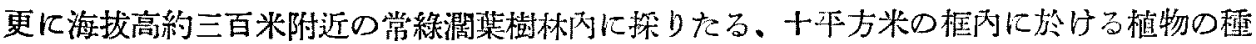

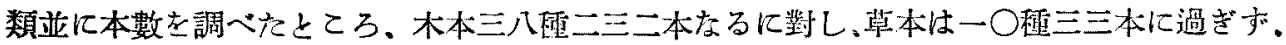
木本の數著しく多的。

(4) 植相變移調查の方法

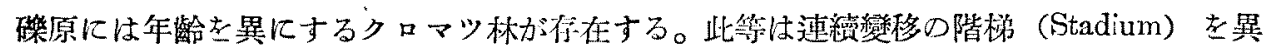
にする群落なりと看做し得るさ以て、此等吉相綜合して以て變移の恹態を推定したのであ る。標潐地選定に當りては、全區域志數回踏查し、然る後に決定せり。框の大さは裸地にて 五本方米、森林內にて十平方米を採り、主としてプラウンブランケー氏並に多ンレー氏の

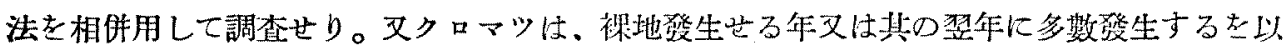

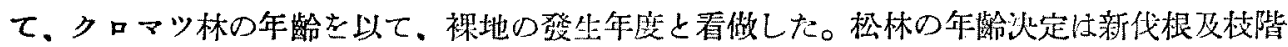
に據つた。

\section{（5）爆發跡地の現狀と連續變移}

既述の如く，眉山は一三儿年前に懪發をなし山麓より海岸に亘る區域吉埋㳢した。而して

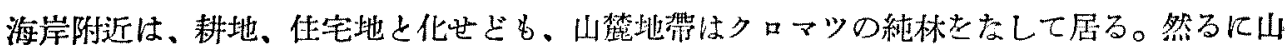

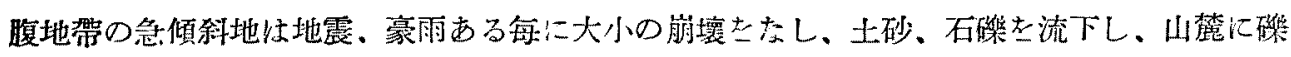
原を形成する。崩壞大なるときは一時クロマツの發生せる磼原立埋沟し、再び裸地を發生し、 更に連續變移を開始するを以て、斯かる個所は植相の連續變移去綜合的に研究士る好材料で ある。

藷者は、斯かる磁原に於ける森林の連續變移を、次の順序にて述へんと思ふ。

(6) 磞原に於ける主要群系列(Hauptserie)

(A)始 原 期 (Anfungsstadium)

流路下部の础原は、殆んど平坦地にして、礫原の下部は砂磁大部分老占め、崩壞區域に近 つくにつれ、直徑大なる石礫を多量に混するるに至る。斯かる醉原に最初侵入する植物は、乾性 
型のもので、多く風に依り散布せらる」に都合良を裝置を何する程子を生產する植物である。

周山础原の全般に亘り、最も先に侵入する植物は、草本として、ヒメムカショモギ、カハ ラハハコの二鋫にして、局部的に發生するはヤハズサウ、マルバヤハズサウ、ススキ、だ。 散在的に小量發生するは、コマツナギ、ヨモギ、の二種である。

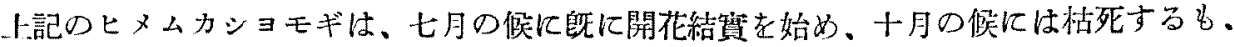
カハラハハコ、ススキの如き宿根草本は七月の候には未控生長十分なら文、秋末に至り開花 結得をなし、一楚の季節的景猚見 (Seasonal aspect) を呈する。

以上は草本類の侵大植物なるが、木本にして前記草本類と同年に、义は翌年に侵入する相 物亡しては、クロマツ、アキグミである。此等二者の多く發生する個所は、一般に水分條件

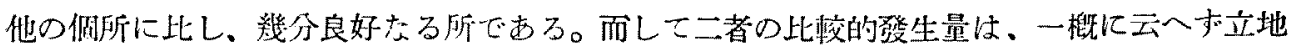
（主として土壤條件）の局部的炎異に關係するが如きも、一般的に觀察するときは、クロマツ

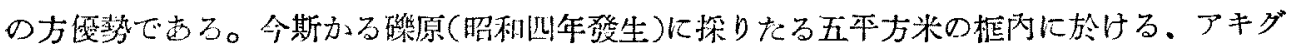
ミ、クロマツ稚樹の發生量起比較して見るに、クロマツ九二本に對して、アキグミは一八本 で遥かに少い。

上記クロマツ、アキグミの外に散在的にクス、入ゼ、アカメガシ八、ネムノキ、イヌザン ショウ等發生する。又細砂地にして、常に水分の倛給する砂磁河畔には、(平水時水深三粝を 出でず）ネコヤナギ、カハヤナギ、ヨシ等の局部的發生を見る。以上の先入植物を見るに、 一般に菌根並に根瘤を有する植物が比較的多數を占むるは注意すべ現象でする。郎ちク口 マツ、アキグミ、ネコヤナギ鹳は菌根植物にして、ヤハズサウ、マルバヤハズサウ、ネムノ キ、コマツナギ等の㟟科植物约皆根瘤を有する。

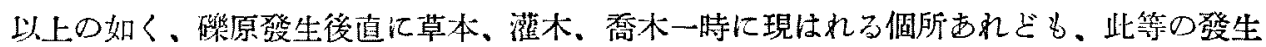
吠態は局部的立地條件の姜異详に附近の現存群落上りの距離、移棑に對する機會の有無等に 任り一栐なら亦。例入ば或る個所には、アキグミ優勢太占め、クロマツは從屬的なる群落を なして居るか上思へば、立地條件大體同一なりと思はれる近接地域にクロマツ传勢を占めて。 アキグミ從屬的なる僠所がある。

以上の如く種の組合せの非異並に量的關係の變化の割合に從つて、そこに現はれる群落の 景相(Physiognomy)を異にするのみならす、植物間の競学關係女異なるを以て、階梯の期間 の上短に影響する。此の始原期時代は、ヒメムカショモギ、カハラハハコ最も優勢なる て、ヒメムカシヨモギ、カハラハハコ群對時と稱するを得る。而してての時代は、期間甚だ 然かく、クロマツ、アキグミが三〜四年生となれば濑次此等草本類老髧し、更に五〜六年生

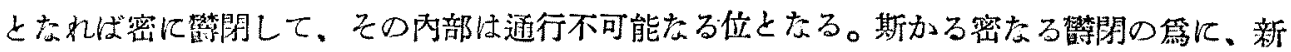
植物の侵入は甚を゙困難となる。出沉於て、クロマツ、アキグミの兩樹整優勢を占むるに至り、 
植相は渐次クロマツ、アキグミ群丵㭙代に變移する。師ちカハラハハコ、ヒメムカショモギ

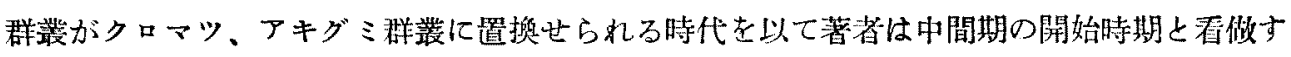
๖のである。

(B)中 間 期( Uebergangsstadium)

斯くしてクロマツ、アキグミガ七〜八年生にもなると前記先入草本は殆ど枯死し、クロマ ッ、アキグミの兩樹種のみが優勢を占むるに至る。乙の時代迄は、アキグミの生長秒クロマ ッ上り早きる、十〜十二年生位になれば、クロマツの生長早くなり、アキグミの生長㳯ふる を以て、遂にアキグミは被厴され、更汇十五〜十六年生にもなれば、アキグミの生長著しく 惡しく、傼かに餘命を保つに過ぎずして濑次枮死するもの多くなる。ての時代にはクロマツ の下枝は枯死し、樹冠は上景し、林內稍柾開するを以て、チガヤを主とし、ススキの侵入起

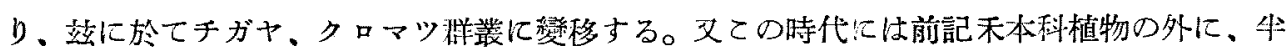

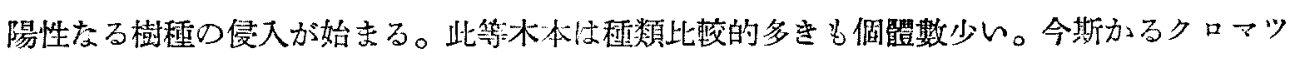
林內に設けたる二十平方米の框中に見出せる稚樹の種類並に個體數をすぐれば、ヒサカキー 本、ヤ、ハゼ一本、アキグミ一本(生長不良)、マルバウツギ二朴、クス一本、シヤシヤンポ 一本、ナナメノキー本、ハクサンボク一本である。

今クロアツ、チガヤ群爜內に於て一般的に見るものをあげると、ヒサカキ、シヤシャンポ、 ナハシログミ、アルバウッギ、ヤマハゼ、クス、ハクサンボク、ナナメノキ等である。此等 の中前三種恃特によく發生する。

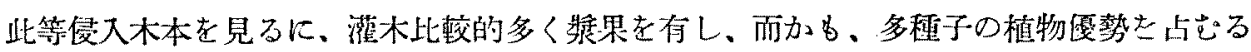
は、恐らく鳥類に依る分布に好都合なる結果と考へられる。(ての意味に於て、鳥類の食性は。 森林の植相連續變移に對し、重要なる關係がある)クロマツ林二○〜二五年生位となれば、 上記の樹種壮、クロマツ林つ下朴として生長し、樹冠を控張するときは、チガヤ、ススキの 生長は渐㳄衰へ、湿木間の空地に僅に殘保するに至る。此等の下木は、クロマツの樹冠上共

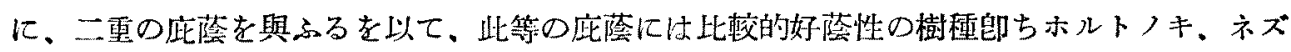
ミモチ、ヒサカキ、クロキ、クチナシ等の稚樹が發生し始かる。この時代は、上記二重の庇

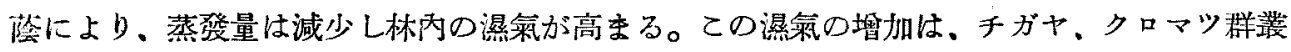
時代には蘚苔類としては、Hypnum 類のみなりしものが、ての時代て至りて濕地を好むスギ

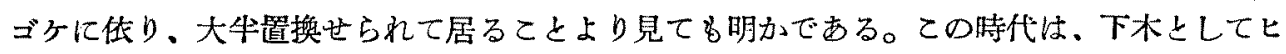

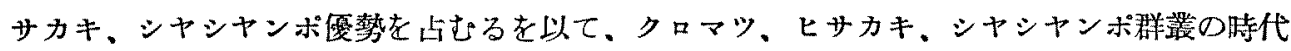
と考へてよい。

クロマツ林三○〜四○年位となれば、林床の灌木以外のクロマツ、チガヤ群僰持代の侵入

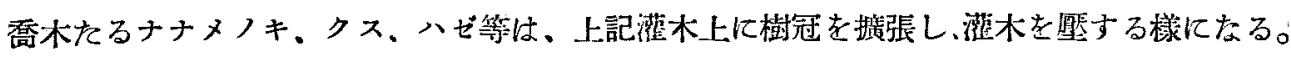




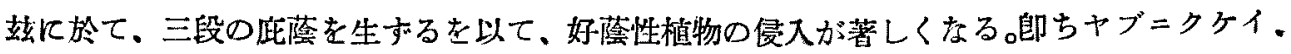
タブ、ヒメニッ゙リ八、トベラ、タスドイダ箁にして、ての時代には、マルバウッギ、ウッギ、

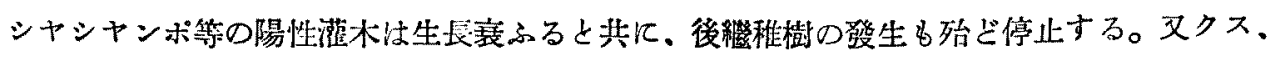

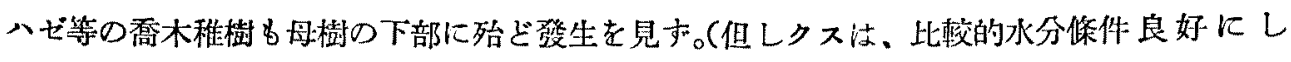
て、腐植質少なき谷通りには、相當の䔖地にも稚樹の發生を見る。)ての時代は、喬木のみが

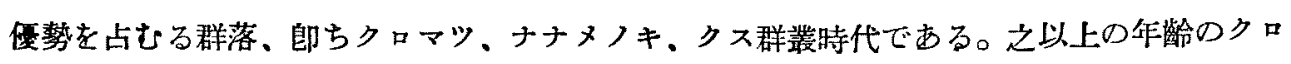
マツ林は础原には存在せす，只础原の上部地圖Aなる個所に九十年生位のクロマツ林存在す る。ての個所は、今上り一三九年前の爆發跡地に成立せるものにして、景相恃針濶混淆林に

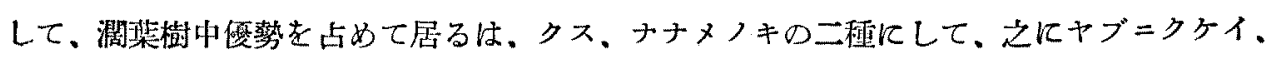
トベラを相當混じて居る。此等濶葉樹中クス、ナナメノキは直徑大なるもの多く、明かに初 期に侵入せるものと思惟される。故に此群落は、明かに磪原の四卜年生位のクロマツ林の一 步淮みねる階梯と洘へられる。今との群落に存在して、磁原のクロマツ林に存在せさる樹種 を舉げると、ツバキ、シロダモ、アアキ、ヤツデ、ヤマモガシ等にして、此等怡若木多く最 近几侵入せるものと考人られる。此等樹種为䃄原のクロマツ林の後階梯に發生するものと荐 へられる。尚地圖Aなる個所を詳細に調查し見るに、クス、マツの稚樹殆發生せず，只ナナ メノキの稚樹は、散存的に發生するも、一般に生長不良でする。然るにヤブニクケイ、トべ ラ、ヒメンヅリハ、シロダモ、ツバキ、タブ等の稚樹は相當䔖地にも盛に發生せる事筫より 思惟するとをは、前記クロマツ、クス、ナナメノキ第の比較的陽性の樹曆は、人第的、地形

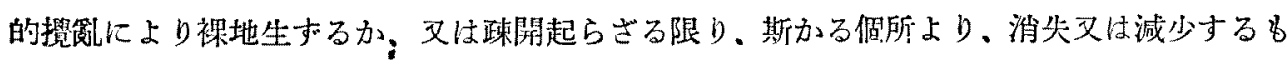
のにあらざるかと考へられる

(C)終 局 期(Endstadium)

以上の如くクロマッ、クス、ナナメノキの本數減少するにつれ、此等の下木圭形成せる夕

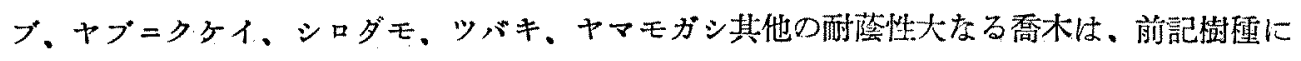
代りて、森林支配するにあらさるかと考へられる。

以上のクロマツ、クス、ナナメノキの消失する順序は不明なるも、此等樹䅜の本數減少並

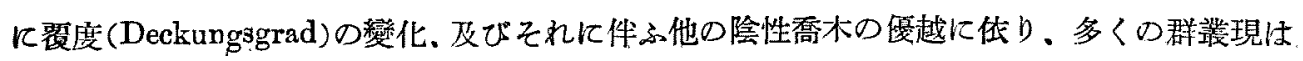
れることは考へられる。

以上は、一般的に起る植相の變移に就き述へたるも、次に此等の變型と見らるるものにつ き述へて見たい。

\section{(7) アキグミ、チガヤ群叢}

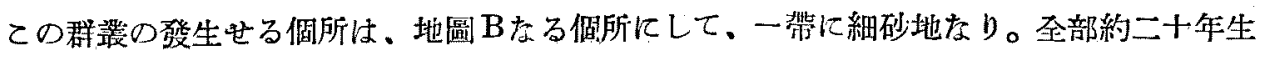
位のアキグミの一齊林にして、散在的に五年〜二○年生位のクロマッを混じて居る。アキグ 
ミの高さは、大體三米位にして、此較的に蹯立せる老以て、その空間には、チガヤ主とし、 コマツナギ、カハラハハコ、ヨモギ、メカルカヤ、ヨカルカヤ等の草本密生して居る。故に 他の樹種の侵入に困難である。斯かるアキグミ林は、始原期にて述べたるが如く、クロマッ を殆ど混ぜさる個所に現はれるものにして、灌木時代の一時的現出なりと考へられる。而し

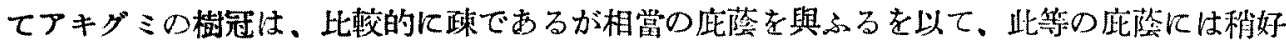
陰性の植物の發生を見て居る。郎ちツュクサ、ヨツバムグラ、スイバ、ヒンダングサ、稀に クス、エフキ、ツルウメモドキの種樹等見られる。此等の草本は隣接せる乾性型の草本群落 と、一つの明かな推移帶を示して居る。斯かるアキグミ、チガヤ群對が將來如何なる方向に 發達するかは、之代けの材料で決定するてとは困難なるも、以上の如くクロマツ漸次侵入し

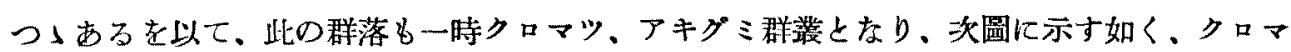
ッ、チガヤ群叢に推移するものにあらざるかと思惟せられる。

(8) クロマツ、チガヤ群叢

此の型は、始原期にて述ぺし所謂アキグミを混ぜざる個所に發達せるるのにして、この群

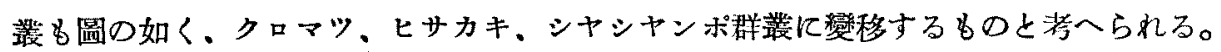

(9) ヤシャブシ、ニシキシツギ群灇

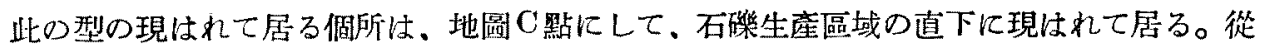
つて石磷の直徑は皆大にして、細土殆を゙なく、加ふるに傾科急にして、水分條件不良なる上 に、上部上りの轉石により石的科面は移動するを以て、斯かる個所には、一般に植物の發生 老見す。只比較的靜止せる㑑所には植物の散在的發生を見る。斯かる個所に發生する植物は、 總て乾性型植物にして、根は地中深く侵入する。今斯かる個所に先入する植物を揭示すれば、 次の如くなる。郎ちヤシャブシ最も多く、之に次をてニシキゥツギ多く，其他散在的に現は れるは、コアカソにして、稀に見るものは、クロマツ、ネムノキ、メルデである。草本にて

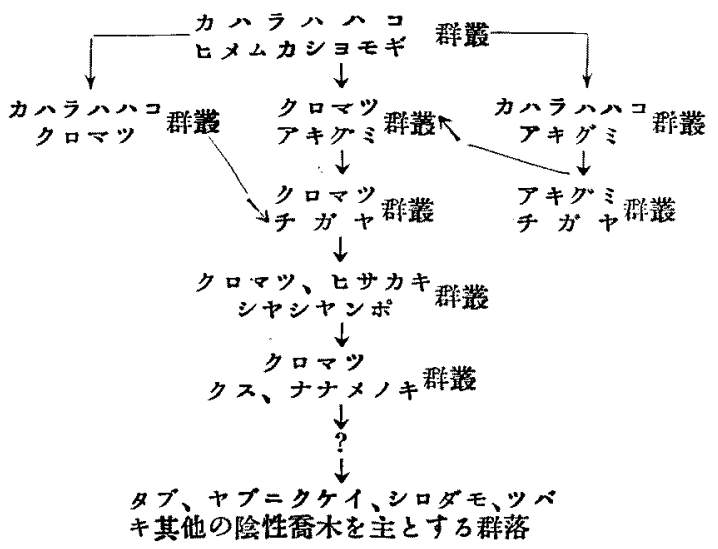


はイタドリ、ススキ、ヨモギ等稀に發生して居る。

此の群绫の將柬の發達は，之以上の階梯の植相を見ざるを以て、不明でする。

今以上の喽原に於ける、連續變移を一覽的に示せば前表の如し。

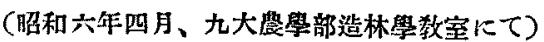

引用文駡

(1) F. E. Clement: Plant succession and indicators.

(2) " Plant ecology.

(3) J. Braun-Blanquet: Pflanzensoziologie.

(4) Werner Liidi: Die Pflanzengesellschaften des Lauterbrunnentales und ihre Sukzession.

（5）中野治房：植物䑾落之其想移

(6) Jansley \& Chipp: Aims and Methods in Stady of Vegetation.

(7) Tansley: Practical plantecology.

(8) Paul-Jaccard: Die statistisch-foristische Methode als Grundlage der Pflanzensoziologie (Handb. d. biol. Arbeitsmethoden)

(9) Warming: Plant ecology

(10) J. A. Larsen: Fires and forest succession in the Bitterroot mountains of Northern Idaho. (Jour. ecol. Vol. X. No. 1)

(11) Toumey: Foundation of silviculture.

\section{○森林樹木の稚苗圖說 第二 糄 柳时由藏著}

本誌へ連載中の「森林樹木稚苗圖說」第一編集錄後の分に就き（第203よ り第 290 迄) 取縓め第二糄として別刷作型の.上希抂者には實費（四拾踐以 內の見込）老以て配布致すべきに付茠望の方は至急本會宛申込末れ度し。

昭和六年七月

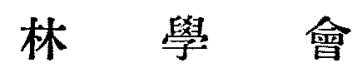

